\title{
Laskaridis and the Hamburg Reefer Cluster
}

The Laskaridis family is today a major player in shipping. In contrast to many of the other players on the reefer scene, the Laskaridis family has since the 1950 s been involved in fishing business. Constantine Laskaridis, after studying ichtyology and applied fishing in Germany, started to work in the Greek Ministry of Economy. Simultaneously, he was involved in running the ship Evridiki, the first Greek fishing vessel to have space for deep-freezing fish ${ }^{1}$. In 1955, he left his job in the Ministry and dedicated himself fully to private business. Together with Dinos Doziadis, he created the company Zephyros, which was involved in ocean fishing, primarily outside West Africa, with five vessels equipped with deep-freeze systems. Some of the respondents have even said that Constantine was the first Greek who went fishing outside West Africa, an area which supplied fish similar to those of the Mediterranean, but in higher quantities. In 1967, Constantine Laskaridis started an independent business, initially with the fishing vessel Kyknos I and later with more ships. The fish was transshipped to reefer vessels, which took the fish to the areas of consumption.

From the mid 1970s, his sons Thanassis and Panos joined the company, after completing their studies in Germany in the field of engineering. Similarly to the description of the Japanese fishing companies, this period witnessed the implementation of the 200 miles Exclusive Economic Zone which hampered Greek fishing interests. The Laskaridis brothers started to work as brokers for chartering reefer ships. From the 1970s the family specialized in the transport of fish, especially by means of transshipment in the ocean.

In the end of the 1970s, the Laskaridis group bought three Japanese fish carriers, with exceptionally large tanks, which created the conditions for a lucrative combination of fish transport and bunker supply to fishing fleets. In the early 1980s, the Nigerian fish importer Primlaks was struck by trouble, and Laskaridis together with Seatrade bought half of Primlaks' fleet of 16 ships each. As fish brokers who needed transport capacity for fish, the Laskaridis family had done quite some business with the International Reefer pool based in Hamburg, which had a large fleet of smaller reefers at the time.

1 For overviews of the history of Greek merchant shipping and the presentation of major Greek shipping families, see Harlaftis, G. 1996. A History of Greek-Owned Shipping. The Making of an International Tramp Fleet, 1830 to the present day, London: Routledge. A brief description of the Laskaridis family's shipping interest is available in Theotokas, I. and Harlaftis, G. 2009. Leadership in World Shipping: Greek Family Firms in International Business, London: Palgrave Macmillan. 
In 1982-1983, Joachim von Reiche, the manager of the International Reefer pool decided that he would like to take on new challenges somewhere else and was therefore looking for alternatives. A particularly interesting alternative was to join the Laskaridis group, which was attractive because of it being a family business, with quick decision making, and an unconventional way of working. Laskaridis who had experience with International Reefer and von Reiche gladly invited him to join. When von Reiche approached his nearest colleagues in the International Reefer pool, they also expressed interest in joining Laskaridis if there was room for them. Given this potenial migration of the managers in the pool, those with know-how, in comparison to the various owners, some owners started the perceive the risk of a brain drain, which would seriously hamper the future prospects of International Reefer. As a result, the German group Harmstorf and the Swiss Alpina group was willing to join von Reiche and Laskaridis.

This was the start of a new pool called Alpha Reefer Transport. The name Alpha came from A as in Alpina, L as in Laskaridis, and Ha has in Harmstorf. Laskaridis also put tonnage into the pool, and in total the fleet was 12 ships of a size of up to $200000 \mathrm{cbf}$. Apart from Alpha, another organization was formed - Frigoship Chartering in Hamburg. This was the exclusive broker of the Alpha pool, and thereby the organization with contacts to the market. In short, Frigoship stood for chartering while Alpha was handling the operation. Also, Frigoship has only one owner which is Laskaridis, while Alpha has several partners.

The Alpha pool grew with new pool members. A Spanish company joined, as well as some banks which had unwillingly become reefer owners. Laskaridis and the Alpha pool was successful in securing tonnage from post-Soviet owners such as Klaipeda, HSC Agency, and Yugreftransport. The other successful player in securing post-Soviet tonnage was Eastwind. Already during the Soviet era, the Laskaridis group had good contacts with Soviet reefer owners, providing various services to the Soviet fleet. The Soviet reefer fleet was before the demise of the Soviet Union exclusively working within the Soviet sphere, which meant that they had basically no experience of competing on an open market, which was very obvious in some early deals where the rumours go that the post-Soviet reefer owners were "taken to the cleaners". From the reefer owners' point of view, joining with Alpha was a way to learn how to operate on a global reefer market. From Alpha's perspective, it was good to increase the number of ships in the pool, to get a broader offering to customers, as well as increasing the income of the pool. Alpha's business was familiar to the new post-Soviet companies, since much was focused around fish. The ex-Soviet vessels were particularly good for transshipment of fish - this was a Soviet specialty. Also, the U.S. started to export chicken legs to Russia, called Bush legs. In 
one year they could export as much as 1.2 million tonnes. The ex-Soviet ships were excellent for carrying deep frozen poultry. The ships also had high iceclass which meant that they could transport the cargo to St Petersburg also during winters. This business has been called a "gold mine". But at the same time, the ships were uneconomical in that they consumed lot of bunkers - the transition to a market economy made some hidden inefficiencies painfully visible. Gradually, some of the post-Soviet ships were scrapped.

However, this boost in tonnage led to Alpha Reefer Transport reaching its peak in controlled tonnage in the early 1990s: 55 ships. In the 199os and first decade of the 200os, the small ships have gradually left the pool since they are not economically viable. This fleet development coincided with the general trend in the second half of the 2oth century towards larger reefers. As of 2015, the smallest ships are of a size of $150000 \mathrm{cbf}$. These ships have proven that fairly small ships can still be economically profitable, if they are employed on special trades, for example servicing ports that can only receive ships of a certain size.

Apart from Alpha Reefer Transport, Laskaridis also owned larger ships of about $400000 \mathrm{cbf}$ which were employed outside the pool, often in the Seatrade pool. Six ships were built in Japan in the end of the 1980 . One reason for building ships in Japan, apart from the high quality of the ships, was that Laskaridis was involved with a Japanese partner in the transportation of squid, and it was favourable to have Japanese built ship for the operation. Also, Laskaridis was very active on the second hand market buying tonnage at good prices. For example, after the Saléninvest bankruptcy, Laskaridis bought a ship from the bank, and the investment cost was recovered in less than a year. It is well agreed by respondents that Laskaridis has a skill to buy tonnage at the bottom of the market. A related skill of the group was to sell ships at the top of the market. Therefore, ships in the Laskaridis group often change owners in order for the ships to always be as profitable as possible for the group.

The trend within the Laskaridis group was an increase in controlled tonnage in the 1990s and 200os, where they gradually bought ships, from companies who were willing to exit this declining industry. In 2003, Laskaridis is said to have placed a bid on Star Reefers which was not accepted by the shareholders. A more successful example was when Maritima del Norte, an independent Spanish operator, having a fleet of eight vessels was split between Seatrade and Laskaridis. Another was when Amer decided to sell its fleet of seven ships in 2008, which were bought by Seatrade, Laskaridis, and others.

Joachim von Reiche, who had been instrumental in increasing Laskaridis impact upon the reefer markets, had in November 2009 a big retirement party, to which many reefer companies were invited. During the party owners of Lavinia and Seatrade met and said that they had to stop competing with each 
other and instead start working together. It was left to the top managers Wolfgang Zielke, who had worked together with von Reiche since the 1970s, and Yntze Buitenwerf from Seatrade to sort out the details. The managers recommended to start on a small scale, but the project escalated and soon Laskaridis wanted to put all his small ships in the pool, and the Norwegian operator Green Reefers wanted to join. The first meeting was in December, and in the beginning of May the pool was operational. It was received with great surprise in the market. The marketing office Hamburg Reefer Chartering was based in Hamburg, and Alpha carried out the operation. Frigoship gave up part of its business and handed it to Hamburg Reefer Chartering. The first two partners were Lavinia and Seatrade, but when Green Reefers joined the fleet size amounted to 110 ships comprising 27 million cbf.

With such a substantial fleet, the company had to be assured that they would not be perceived as monopolistic according to EU monopoly law. According to the consulted laywers, the share of the pool in relation to worldwide transportation was too small to have an impact. However, there is no doubt that the impact was significant in the particular segment - small reefers - that the company was operating in. Some say that the market share of Hamburg Reefer Chartering was as high as $80-90 \%$ of the world fleet in that size segment.

As with many other cooperations that we have seen in the book, Hamburg Reefer Chartering was shortlived. But according to respondents, they succeeded with one major thing. When the pool went operational, an analysis was done to see how many ships were required. It was found that only about 75$80 \%$ of the capacity was needed. Given this analysis, it was decided to scrap 20 ships, or every partner had to scrap seven ships. A special bonus was given to those who agreed to scrap their ships - if they would scrap the ship as of 1 January 2011, they were offered 500000 USD of scrapping bonus plus the fact that the ships would be part of the pool virtually until the end of June, that is getting additional earnings of a year without even having a ship in the pool. The strategy was successful, and it is quite obvious that this has impacted on the charter rates of ships in the small segment. If the partners had not joined a pool together, no such concerted effort would have been possible.

But Seatrade was uncomfortable in the relationship and decided to discontinue the joint work. As with many of the break-ups seen in this book, this can probably be attributed to a number of factors ranging from operational philosophy and money to control, power and cultural aspects. Green also decided to leave Laskaridis in 2012 and join Seatrade, forming the GreenSea pool of 48 ships.

From 2011, the former operation of Frigoship and Alpha was reactivated, starting with 24-25 ships. Laskaridis withdrew his ships from the Seatrade pool, effectively ending all connections to Seatrade, and the number of ships in the 
Alpha pool increased to 45. Limarko, formerly Klaipeda, one of the early members, is still part of the pool. HSC Agency is run by the former managing director of Klaipeda, Aveny Bich, owning a few ships. Yugreftransport, formerly from Sevastopol, are now located in St Petersburg. Agder is a Norwegian investor, with a few ships in the pool. Fairport is run by the Greek Kalimassias - a major competitor to Hamburg Reefer Chartering - who has five ships in the pool. As of 2014, Laskaridis owned 27 (reefer) vessels.

Laskaridis states that "We have a view, which we have consistently held for the last 20 years, that eventually everything that can be containerised will be containerised" 2 . This is a reason for which Lavinia is specializing on open sea transshipments, which is still a conventional reefer specialty. There is a constant risk that the need for conventional reefers doing open sea transshipments will decline. If the catch is brought to port, container lines can be used to ship the fish to the market. Furthermore, bringing the fish to port can increase the state's control over the catch, as well as possibly creating employment ashore. However, it is plausible that fishing companies would like their trawlers to remain in the fishing grounds, which means that there will be some need for transshipment. The business will therefore not die overnight, but will most probably see a gradual decline. Laskaridis said, "You could call [the reefer trade] a business in a run-off mode, but it is a slow, profitable run-off, and as things seem today we may have to re-invest in a few ships to continue servicing very specific trades" 3 .

Apart from the reefers Lavinia has interest in more than 30 bulkers, tankers for supplying bunkers to fishing fleets, and two factory trawlers. The company has thus remained in a niche of the reefer market, while building up a fleet that is unaffected by the decline in the conventional reefer market.

\section{Eimskip}

Another reefer operator with a close link to the fishing industry is Iceland's Eimskip. The company was originally founded as Eimskipafélag Íslands (Iceland Steamship Co) in 1914, thousands of Icelanders proudly purchased shares in the company that would end Iceland's reliance on Danish shipping. The first two ships, the Gullfoss and Godafoss arrived in 1915, both named after waterfalls, a tradition that has persisted ${ }^{\mathrm{a}}$. The company started sailing to America in 1917 due to the war and in 1926 the first vessel with temperature control, Brúarfoss was added to the fleet ${ }^{b}$. Shipping fish from Iceland and returning with miscellaneous cargo was the main business for many years but the company also diversified.

2 "Going in for the krill". TradeWinds 23 May 2014

3 "Going in for the krill". TradeWinds 23 May 2014 
Eimskip dramatically expanded in the 2000 s, by 2007 they operated 50 ships and was the largest cold-storage provider in the world ${ }^{c}$. However, the company crashed as a result of Iceland's banking crisis ${ }^{\text {d }}$, but there were also other factors, and recorded a net loss of 645 million Euro for the year ended 31 October $2008^{\mathrm{e}}$.

Creditors took control over the company, it was reconstructed and the cold-storage business sold. The shipping business remained and returned to a North Atlantic focus and has been a profitable niche player in the reefer market ever since. In later years they have acquired several companies with a focus on freight forwarding but have also invested in cold stores and harbour infrastructuref ${ }^{f}$. In 2018 they had a weekly service from Iceland to Portland Maine also calling on Halifax and Newfoundland, several lines connecting Iceland to Northern Europe, many calling on the Faeroe Islands, and also a line servicing ports in Norway and continuing on to Murmansk. Fish and seafood was the most important cargo. Besides three ferries Eimskip operated 19 fairly small vessels, 10 owned and 9 chartered. Some of these are specialized reefers and the remainder are container vessels with reefer capacityg.

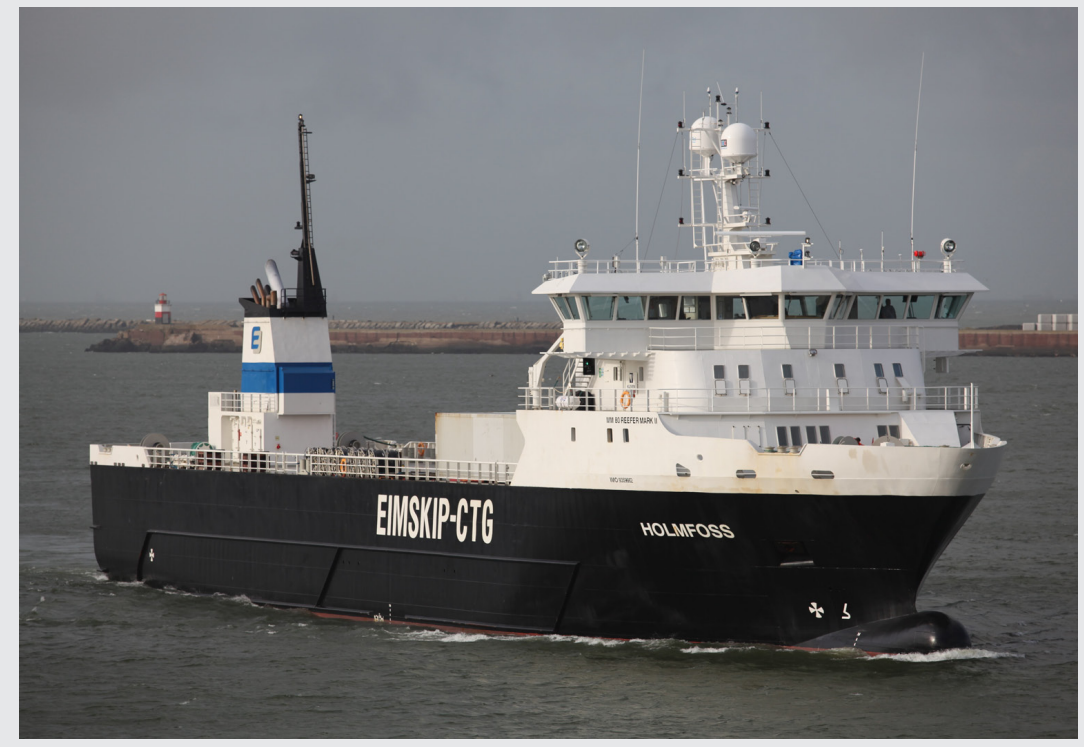

FIGURE 21 Small reefers like the Holmfoss connect Norway's fishing ports and Murmansk to the UK and the Continent. This vessel was delivered in 2008 and can handle different temperatures in its five holds. Eighty metres long, it can carry 28 FEU containers, with reefer plugs, and is rated to operate in one metre thick ice

PHOTO: JOOST J BAKKER 
Notes: a Jóhannesson, G.T. 2013. The History of Iceland, Greenwood: Santa Barbara, p. 96; b Eimskip webpage <http://edit.eimskip.is/EN/about/history/default.html>; c Hf. Eimskipafélag Íslands Annual Report 2007, p. 6; d On the Icelandic banking crisis see for example Boyes, R. 2009. Meltdown Iceland, London: Bloomsbury. For a perspective by a central figure connected to the crisis and to Eimskip see Bjorgolfsson T. 2014. Billions to Bust - and Back, London: Profile Books; e Hf. Eimskipafélag Íslands Annual Report 2007, p. 5; Eimskip Annual Report 2017 p. 2; g Eimskip webpage <https://www.eimskip.com>

Hamburg Süd, a short version of the original name Hamburg Südamerikanische Dampfschifffahrts-Gesellshaft, is a liner operator that since 1871 has been focusing on North-South trades. While originally owned by a group of merchant houses, the Oetker family acquired an interest in the company in 1936. Hamburg Süd was a major operation and boasted a fleet of 50 ships in 1939. Both world wars led to a complete loss of the fleet, but from 1951 the liner service between Europe and the South American East Coast was resumed. In 1952, the business expanded to tramp shipping. During the 1950s, Hamburg Süd started to develop its tramp reefer business. In the early 1950s they chartered tonnage, and later bought reefer vessels. The 1950s was also, according to respondents, the decade when the small tramp reefers started to appear on the market, with players such as Gustaf Erikson. This entry into the reefer segment was, however, not their first experience with carrying reefer cargo, their liner vessels had also carried reefer cargo. In the 196os a typical liner vessel in the Hamburg Süd fleet would have a cargo hold for refrigerated goods of about 150 000 to $200000 \mathrm{cbf}$. It has been told that such liner vessels loaded mainly meat in Argentina and orange concentrate in Brazil on the way to the us or Europe.

Hamburg Süd saw the potential of the reefer market, which was deemed much more attractive than the general cargo segment which saw a slump in the latter half of the 1950s. Hamburg Süd also followed the growing import of bananas closely, where per capita consumption increased rapidly. The company wanted part of this high-growth segment. Also, Hamburg Süd was now part of the Oetker conglomerate, which had significant financial resources, and were willing to invest in tonnage, not only because of the interest in shipping, but also because of the attractive tax conditions associated with ship investment.

In 1960, Hamburg Süd had 16 reefers from about 120 ooo cbf to $230000 \mathrm{cbf}$. Although these ships were already big compared to the small tonnage that appeared in the 1950s on the tramp market, Hamburg Süd envied JLauritzen's red painted ship of $270000 \mathrm{cbf}$. In the early half of the 1960s a new series was built 
with vessels of the size of 300 ooo cbf, and in 1968 vessels of 420 ooo cbf were built. We can therefore see an increase in ship size, and representatives of Hamburg Süd felt they were a major part of the trend of building larger reefer tonnage. The Polar class ships had an operating speed at banana draught of 23.5 knots and had a capacity of about 420 ooo cbf. The Polar ships were chartered out to Salén for banana trades. The ships of $300000 \mathrm{cbf}$ were on a fiveyear timecharter to Standard Fruit. About 50\% of Hamburg Süd's reefer division was dedicated to carrying bananas. Part of the fleet was also servicing fruit trades from Chile, Argentina, and New Zealand. The smaller ships were chartered to German fruit importers on a yearly basis. The ships were also doing tramp business, voyage charters, for example exporting chicken from the Us to Europe. For the ships around $200000 \mathrm{cbf}$, they were often chartered to Salén for nine months, and then the ship went to drydock when it was redelivered in June/July, and then employed on the spot market during the Northern summer. The reason why many ships were fixed to Salén was because they offered the best rates - which is an indication that they could use their extensive fleet and network to reach synergies.

Hamburg Süd were also agents for a fleet of 18 ships, from $30000 \mathrm{cbf}$ up to 60 ooo cbf. These are very small reefers that sailed the Norwegian coast carrying fish. In that time, small ships could go as far as South America, into the Great Lakes, to the Middle East, and to New Zealand. The margins were there, the income was good and labour costs and bunkers were cheap. Times were good in the reefer business, which was of course a reason for small tramp reefers being developed. They were also trading between India and the Gulf ports with bananas and livestock. Another cargo was blueberries from Poland and Sweden to Germany.

There were some synergies between the reefer and the liners. In contrast to for example NYK which had reefers operating North-South and liners EastWest, both the reefers and liners potentially operated on the North-South routes. At times, when the liner vessels did not have enough capacity to carry all the cold cargo from South to North, they contacted the reefer department and asked for additional tonnage, which was either supplied from the in-house fleet, or more commonly chartered in from the open market. This would have been more difficult if Hamburg Süd didn't have its own presence in this market. Sometimes, the liner departments used reefers as dry cargo ships, carrying coffee and other non-refrigerated cargo. Since the reefer division operated on the global market, their chartering staff also learned about profitable refrigerated cargo that could be carried by the liner vessels, for example potatoes from Europe to South America. In that way, the liner department could get a better 
yield on the voyage from North to South. However, the fact remained that the liner and reefer divisions had different mindsets. One was engaged in regular trade with a timetable and the other was more oriented towards the spot market. The liner division was working with smaller quantities and the reefer division with larger quantities of cargo: "in the liner operation you have 100 tons here and there. In reefers we are thinking 10000 tons of bananas, 5000 tons of meat".

The 1960s were very good for the reefer division of Hamburg Süd, but the market suffered a downturn at the end of the decade. For the group this was compensated with better earnings on the liner side. As a response to the decline in the reefer market, Hamburg Süd started to sell its smaller reefers, those smaller than $200000 \mathrm{cbf}$. This decision was partly due to the slump in the reefer market and partly due to the fact that containerization started for Hamburg Süd in the late 196os. It started out in Australia with Columbus Line, an affiliated company, carrying meat from Australia to the Us. Financial means had to be focused on the investment into container ships and containers. Although, the containerization would lead to more reefer capacity on the new container vessels than in the previous liner vessels, it redirected attention away from conventional reefers, especially smaller reefers.

While Hamburg Süd had been agents for the fleet of smaller reefers, in 1970, Joachim von Reiche was asked to be the manager of a pool of small reefers, called International Reefer. This pool was concentrated on marketing a common fleet of small reefers from 60 ooo to 130 ooo cbf, supplied by 12 shipowners. The idea was to get a broader coverage of the market by working together. The pool also functioned as an information hub, where the owners could get information about the present and potential futures of the reefer market. This information function was already present at Hamburg Süd when they were handling the small reefers but was now set up as a stand-alone unit. This could be compared to the Leonina pool of Cool Carriers, which was also an information hub. Furthermore, by employing the ships in a pool, each of the participating owners didn't require in-house chartering personnel - but could outsource that to the pool, cutting labour costs. However, the owners were still in charge of the operation of their ships. Like other pools, the earnings from the pool were shared between the partners given the ships capacity, speed, fuel consumption and any extra frills, such as cargo handling gear, etc. From the beginning, this pool had 18 ships, but it grew to a maximum of 35 . 


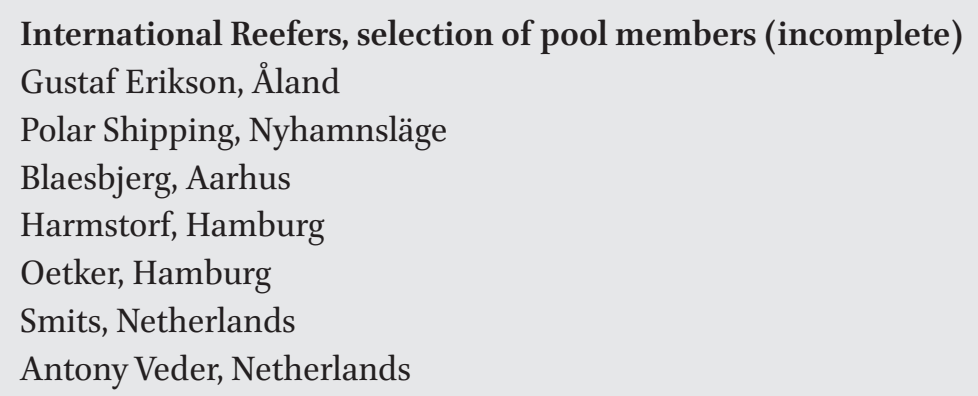

In 1974, Wolfgang Zielke started to work at Hamburg Süd. He recalls that these were the glorious days for reefer ships. Germany operated a substantial fleet, with companies such as Ahrenkiel, Bruns, Ianka, Luhmann, Horn, and the International Reefer pool. The German-owned ships were often built in Germany at shipyards such as Sietas, HDw Hamburg, and Blohm \& Voss.

In 1979, Hamburg Süd took delivery of two reefers of 480 ooo cbf. They were chartered to Castle and Cook, Dole, but just after two years, the collaboration was discontinued. Rather than collaborating with Hamburg Süd, Castle and Cook, Dole acquired the reefer fleet of Bruns - another German reefer player - of about 10 ships. In the 1970s and early 1980s, Hamburg Süd had a fleet of about 15 owned and chartered reefers. The large Polar ships were still on charter to Salén. Some smaller ships were left in the fleet and employed in the International Reefer pool. However, it was clear that Hamburg Süd was no longer interested in building their reefer fleet. Rather, the situation was one of gradual decline. The Polar ships were sold and chartered back for a few years. At that time, Joachim von Reiche from International Reefer had started to work together with Laskaridis and was interested in making Hamburg Süd join with Laskaridis. However, in 1986, Hamburg Süd decided to collaborate with Star Reefers and moved all the chartering operation for the larger ships to London.

\section{$2 \quad$ Summary}

Similarly to SKG (Seatrade), Hamburg Süd experienced a downturn of the general cargo markets in the late 1950s and also saw that the import of bananas to Germany was increasing significantly. Therefore, they decided to invest in reefers. In contrast to other liner companies such as Blue Star Line and NYK, Hamburg Süd's lines were North-South which made it possible to create synergies between the liner and specialized reefer segment. They subjectively perceived the larger reefers to be more prestigious, which was a reason that they 
continually built larger ships. Smaller ships were spun out into International Reefers in 1970. Due to the focus on the liner operation, Hamburg Süd's specialized reefer operation gradually declined and in 1986 a collaboration was made with Star Reefers which moved the operation of larger ships to London.

Laskaridis started out as a fishing company but expanded to be a reefer operator focused on fish transports in the 1970s. Similarly to Seatrade, and in contrast to Lauritzen and Saléns, Laskaridis was focusing on fish transports. To gain more market knowledge and customer connections Laskaridis worked with the Hamburg cluster, similar to how other companies have approached the Stockholm cluster to get competent personnel. With a base in Hamburg, Laskaridis started the Alpha pool in the early 1980s. Given Laskaridis' sense for business, seen as fast and unconventional, the company managed to get their hands on post-Soviet tonnage in the early 199os. Given the increased competition and lower profitability in the 199os the smaller ships were phased out. Given Laskaridis' willingness and ability to invest, the company was able to buy tonnage from distressed owners and banks. A large-scale collaboration was Hamburg Reefer Chartering which had a fleet of over 100 ships. However, it is difficult to collaborate and in 2011 Laskaridis left the pool and recommenced an independent operation. Laskaridis, similar to other Greek owners, has been subjectively understood, by the largest players such as Lauritzen and Cool Carriers, as a second-tier player, operating with old tonnage on secondtier trades. Still, it must be said that profitability does not always follow pride, and Laskaridis is seen by many to have been highly profitable over the years, in contrast to Lauritzen and Cool Carriers. 


\section{PART 3}

\section{Container Lines and Shippers}


As we described in the introductory chapter, there are a variety of actors in the cold chain. All these actors have had an impact on the historical development of the independent reefer operators. In this part, we describe two kinds of actors. First, we describe container lines, using the example of Maersk. Liner companies have always been a major competitor to the independent reefer operators. We describe Maersk in order to see the reefer industry from another perspective to understand the independent reefer operators' competitors. Second, we describe fruit companies and marketing boards which have been important customers of the independent reefer operators. 